\title{
Mothers' Perceptions of Social Support during the Postpartum Period: A Qualitative Study on Psychological Well-Being of Mothers
}

\section{Annelerin Doğum Sonrası Döneme İlişkin Sosyal Destek Algıları: Annelerin Psikolojik İyi Oluşları Üzerine} Nitel Bir İnceleme

\section{Zuhal Beyza GÜLER ${ }^{1}$, Ozden YALCINKAYA ALKAR ${ }^{2}$}

\begin{abstract}
It was aimed to understand mothers' perceptions of social support and their expectations during the postpartum period in this study. For this aim, the interview technique was used. For the study, 17 participants who gave birth within the last 6 months in Turkey were interviewed with open-ended questions via phone. It was tried to elaborate on social support in the postpartum period with detailed discussions with them. Using content analysis, the results were collected under three main themes, the most expected matter for support, expectations from mothers and mothers-in-law, and expectations from their partners in the postpartum period. With the main themes, 14 sub-themes were identified. Each sub-theme was discussed elaborately in the study. The result of this study shows that mothers can perceive some behaviors as support negatively. Based on the results, it can be said the content of the support is more important than the existence of social support for mothers. Also, who gives which type of support is important for them. In short, the expectations of mothers as social support should be considered in the postpartum period for their psychological well-being.
\end{abstract}

Keywords: Mothers, Postpartum Period, Qualitative Research, Social Support

\section{Öz}

$\mathrm{Bu}$ çalışmada, annelerin doğum sonrası döneme ilişkin sosyal destek algılarının ve beklentilerinin anlaşılması amaçlanmıştır. $\mathrm{Bu}$ amaç kapsamında, Türkiye'nin çeşitli yerlerinden, son 6 ay içinde doğum yapmış 17 anne ile açık uçlu sorulardan oluşan yarı yapılandırılmış form kullanılarak görüşülmüsştür. Annelerle gerçekleştirilen görüşmeler ile birlikte doğum sonrası döneme ilişkin sosyal destek kavramı detaylandırılmaya çalışılmıştır. Sonuçlar içerik analizi kullanılarak analiz edilmiştir. Analiz sonuçları, doğum sonrası dönemde en çok destek beklenilen konu, annelerden ve kayınvalidelerden beklentiler ve eşlerden beklentiler olmak üzere üç ana tema altında toplanmıştır. Belirlenen bu üç ana tema altında toplamda 14 alt tema belirlenmiştir. Çalışmada her bir alt tema ayrıntılı olarak tartışılmış̦ır. Bu çalışmanın sonuçları, sosyal destek amacıyla sergilenen bazı davranışların yeni doğum yapmış anneler tarafindan olumsuz olarak algılanabileceğini göstermektedir. Elde edilen sonuçlara dayanarak doğum sonrası dönemde sosyal desteğin varlığından ziyade sosyal destek içeriğinin daha önemli olduğu ifade edilebilir. Verilen desteğin içeriğine ek olarak, desteği veren kişinin kim olduğu da bu dönemde anneler açısından önemlidir. Kısacası doğum sonrası dönemde annelerin psikolojik iyi oluşları açısından, onların sosyal destek olarak beklentileri göz önünde bulundurulmalıdır.

Anahtar Kelimeler: Anneler, Postpartum Dönem, Niteleyici Araştırma, Sosyal Destek

This study was decided to be ethically and scientifically appropriate by the Ankara Yildirim Beyazit University Human Subjects Ethics Committee (Date: 04.03.2020, Decision No: 47, Number: 2020-88).

${ }^{1}$ Student, Zuhal Beyza GÜLER, Clinical Psychology, Ankara Yildirim Beyazit University, beyzaatak13@ gmail.com, ORCID: 0000-00022664-4205

${ }^{2}$ Prof. Dr., Ozden YALCINKAYA ALKAR, Psychology, Ankara Yildirim Beyazit University, ozdenalkar@ yahoo.com, ORCID: 0000-00018484-9199 


\section{INTRODUCTION}

Born of a baby brings several changes for families. ${ }^{1}$ Although the birth of a new baby is considered a happy situation for families, it also brings many stressful processes. Being in a stressful period with born of the baby affects new mothers, the baby, and marital relationships. ${ }^{2}$ Thus, it is important to be aware of the problems that can be encountered in this period and get over this period better.

The postpartum period is a stressful period after birth. Although it is popularly known as the postpartum period about 40 days, the postpartum period can be up to one year. ${ }^{3}$ In this period, mothers can experience several difficulties. This period can affect the psychological health of mothers negatively. It can be risky in terms of mood disorders for mothers. ${ }^{4}$ Postpartum depression, postpartum blues, anxiety disorders are some of the common mood disorders that occur one year after birth. ${ }^{3-6}$ Additionally, postpartum psychosis is another psychiatric problem seen in this period. ${ }^{7}$

It can be added that problems in marital relationships are another important problem area in this period. ${ }^{8}$ Both mothers and fathers, especially mothers, consume their time and energy for baby care. They try to adapt to their new roles. This adaptation can be stressful for them. They project their tiredness and stress to their partners. ${ }^{9}$ These problems also affect their sexual relationships and so their relationships. ${ }^{10}$ In addition to differences in marital relationships, with the baby, the layout of the house is changing. Thus, there can also be some financial and household problems. ${ }^{7}$

In short, the postpartum period affects people's marital life, the physical and psychological health of the mother, and the health and well-being of the baby. ${ }^{11}$ In addition to being a challenging process for mothers, the difficulties in this period can harm the relationship between mother and baby and the cognitive and emotional development of the baby. ${ }^{12}$ Based on these, the postpartum period should not be ignored.
In addition to the importance of this period, it is the period in which parents can need the most information and support. ${ }^{13}$ Therefore, social support in this period is important, and it helps decrease in experiencing the problems mentioned. ${ }^{14,15}$

Social support in the postpartum period is defined as support for baby care, housework, and emotional support from the environment for new mothers. ${ }^{16}$ Social support is categorized into three groups: emotional support, informational support, and instrumental support. Emotional support is the expression of care, interest, and value to new mothers. Informative support is advising on baby care to them, while instrumental support is financial support and assistance with housework. ${ }^{17}$ From the general point, support can be either in explicit or implicit form. Expecting advice or help from others is explicit support. Knowing others are with them in this period without expecting any help their difficulties are implicit support. ${ }^{18}$

After giving this information, it can be asked how social support affects new mothers. Studies emphasize the stressbuffering effect of social support also in the postpartum period. ${ }^{15,19}$ Studies have found a negative relationship between social support and the existence of psychological problems in the postpartum period. It is also claimed that a lack of social support in this period is a risk factor for psychological problems like postpartum depression., ${ }^{3,20}$ In short, studies emphasized the importance of social support in the postpartum period; and indicated low social support is a risk factor for new mothers' psychological and even physical health. ${ }^{14,15}$

However, there are also some studies showing that social support is not a protective factor to undergo this period better. For instance, Logsdon and his colleagues found that mothers in the postpartum period claimed that they did not receive much less help than they expected, and low social support was not associated with having psychological problems. ${ }^{21}$ 
Additionally, a study with Taiwanese mothers found that new mothers who stayed with their mothers-in-law to get help showed more depressive symptoms during the postpartum period. ${ }^{22}$ Based on these, it can be said social support is not always positive for new mothers. Therefore, what is the effect of social support in the postpartum period can be elaborated in the literature.

Based on the information in the literature, studies differ from the results about the effect of social support in the postpartum period. Here, mothers' expectations from their environment and perception of support are important. For example, although mothers think that social support is critical, the lack of social support can be effective for developing psychological problems in this period if they receive less support. ${ }^{21}$ Furthermore, the effect of social support can be changed between cultures. $^{22,23}$ In individualistic cultures, explicit support can be more important while in collectivistic cultures, implicit support can be more important. ${ }^{18}$ Also, it matters who gives them the support. ${ }^{24}$ Thus, it should not be generalized that social support affects new mothers positively.

It is unknown well the effect of social support in the postpartum period in Turkey being one of the collectivistic cultures. The current study aims to elaborate on the effect of social support on the postpartum period like which type of support is important or from whom mothers expect the most support. Moreover, there is not any qualitative study on mothers' expectations about social support in Turkey. Thus, the aim of the current study is also to obtain information about these topics from new mothers in Turkey using a semi-structured form. With these aims, the current study presents qualitative research on the postpartum period in the literature.

\section{MATERIALS AND METHODS}

\section{Qualitative Approach}

The qualitative research was conducted in the study, and content analysis is used for the qualitative study. In content analysis, the content of the communication is identified objectively and systematically. ${ }^{25}$

\section{Place and Time of the Research}

Data were collected between March and May 2020 from mothers giving birth within the last 6 months from different provinces in Turkey.

\section{Participants}

17 mothers giving birth within the last 6 months were interviewed as participants for the study. Participants were selected through convenience sampling. All participants are married and live with their babies' fathers. Their age range is between 23 and 34, with a mean of 28.24 years $(\mathrm{SD}=2.79)$. The age of participants' babies is a mean of 4.29 monthold (SD=2.02). The demographic characteristics of participants are presented in Table 1.
Table 1. Demographic Characteristics of the Participants

\begin{tabular}{cllr}
\hline Variable & $\begin{array}{l}\text { Percentage } \\
(\mathbf{N})\end{array}$ & $\begin{array}{l}\text { Mean } \\
(\text { SD) }\end{array}$ & Range \\
\hline Age of Mother & & 28.24 & $23-34$ \\
& & $(2.79)$ & \\
\hline
\end{tabular}

\begin{tabular}{|c|c|c|c|}
\hline Education & & & \\
\hline Level & & & \\
\hline Secondary & $11.8(2)$ & & \\
\hline School & & & \\
\hline High School & $29.4(5)$ & & \\
\hline Bachelor & $58.8(10)$ & & \\
\hline $\begin{array}{l}\text { Employment } \\
\text { Status }\end{array}$ & & & \\
\hline Working & $58.8(10)$ & & \\
\hline Homemaker & $41.2(7)$ & & \\
\hline $\begin{array}{l}\text { Number of } \\
\text { Marriage }\end{array}$ & & & \\
\hline First Marriage & $94.1(16)$ & & \\
\hline $\begin{array}{l}\text { Second } \\
\text { Marriage }\end{array}$ & $5.9(1)$ & & \\
\hline $\begin{array}{l}\text { Year of } \\
\text { Marriage }\end{array}$ & & $\begin{array}{l}4.44 \\
(2.47) \\
\end{array}$ & $1.5-9$ \\
\hline Age of Father & & $\begin{array}{l}30.23 \\
(2.58)\end{array}$ & $26-34$ \\
\hline
\end{tabular}


Table 1. (Continuation) Demographic Characteristics of the Participants

\begin{tabular}{lr}
\hline Income & $23.5(4)$ \\
Low & - \\
Medium & $76.5(13)$ \\
High & \\
\hline Children & $76.5(13)$ \\
First Child & $23.5(4)$ \\
Second Child & \\
\hline Gender of & \\
Newborn & \\
Baby & \\
Girl & $58.8(10)$ \\
Boy & $41.2(7)$ \\
\hline Pregnancy & \\
Willingly, & $88.2(15)$ \\
Planned & \\
Unplanned & $11.8(2)$ \\
\hline
\end{tabular}

\section{Data Collection Methods}

Demographic Form and Questions about Birth: There were questions about their age, their income level, education level, employment status, marital status, the number of their marriage, the year of marriage, the age of their partner, the information about their child, and birth like the number of their baby, gender of the baby, age of the baby and birth method in this form.

Open-ended Questions Form: It was used to learn mothers' perceptions of social support and their expectations in the postpartum period. The questions in this form were what is their challenge after birth, in which matters and from whom they receive the most support, what they expect from their environment as support, what and which behaviors annoy them from their environment in this period.

\section{Data Collection and Analysis}

After receiving ethical approval, participants were reached. First, it was planned to meet face to face with participants. However, because of the COVID-19 epidemic in Turkey when the study started, the data had to be collected by phone. After participants read the informed consent and admitted to participating voluntarily, demographic questions were delivered. Informed consent was given to the participants with an e-mail or a message.
Next, they were interviewed by phone to ask questions in open-ended questions form. They were asked to be in a quiet and appropriate environment where no one was with them. The interview lasted about 20 min. Also, it was summarized the points and reaffirm the views on the subject with the last question "What do you want to say to people in general about this period?" to increase the validity and reliability of the study. Moreover, the quality of the information is more important than the number of participants for quantitative studies. ${ }^{26}$ Sample saturation is considered to finish collecting data. Thus, when the data started to repeat and new information was not taken from the participants, it was thought that enough participants were interviewed, and data collection finished. After interviews were completed, based on the answers given to the questions, the main themes were determined. The interviews were manually written verbatim. The analysis of the data process was conducted in the form of encoding the most common words and thoughts after repeatedly reading the recordings that were written to the computer using Word application. Qualitative data analysis was performed manually while the Statistical Package for the Social Sciences (SPSS) program was used for the data in the demographic data form.

\section{Aspect of Research Ethics}

The study has the necessary permissions and ethical approval from Ankara Yildirim Beyazit University Human Subjects Ethics Committee with the research code 2020-88 (Date: 04.03.2020). General information and the purpose of the study were given to the participants in the informed consent. The confidentiality of the participants was saved using P1, P2, etc., in the data and quotations in the study. Also, the data were stored in a password-protected computer.

\section{Limitations of the Study}

The study has several limitations. First, the sample size is small. There can be a need to increase the sample size for the generalizability of the results. The study was conducted in Turkey, a collectivistic culture. 
There can be some problems to generalize the results between cultures. The qualitative studies on the postpartum period and social support must increase to see the effect of the culture. Lastly, the study was conducted in an epidemic period. The period for the study was the beginning of the COVID-19 pandemic. Mothers can be more stressed because of the effect of the period. Thus, the study can be replicated in another period. All can help for extensive, detailed, and different information to understand and make sense of postpartum period and new mothers.

\section{Financial Support}

The authors received no financial support for the research.

\section{Conflict of Interest}

The authors declare no conflict of interest in the study.

\section{Acknowledgment}

The authors are thankful to the participant mothers.

\section{RESULTS AND DISCUSSION}

When the answers from interviews were analyzed, various answer categories were created. Researchers gave a name for each category and created annotated examples for each one. There were 3 main themes as a result of thematic content analysis of the transcripts. The names of the themes were the most expected matter for support, expectations from mothers and mothers-inlaw, and expectations from the partners in the postpartum period.

First, the most expected matter for support theme was categorized into four categories. The first one was assistance with housework. According to the transcripts, most of the participants (seven of them) expect support for housework. Moreover, it can be added that assistance with cooking was one of the most important supports in this period. Most of the participants said they got hungry a lot because of breastfeeding. They had to eat well so that the milk was enough for the baby.

"I felt like I was on the street alone with my baby. There were many dishes on the countertop in the kitchen. Laundry would be like a mountain. There was no cooking in the kitchen. You were in a position of breastfeeding. You were always hungry. You waited for someone to come and make a soup. I do not expect people to look after my baby. I can look after my baby, but they should help me with housework." (P2).
"I was exhausted. I did not take care of my baby as I wanted because of my responsibilities, such as cooking and cleaning. Thus, there should be someone to make housework for us." (P4).

"There was no sleep but was constant breastfeeding. The new mother became exhausted. She needs someone to prepare food for her. There was no need to say new mothers need support for cooking and cleaning in this period." (P5).

The second emerging category was support for the care of the older child.

"I had another 4-year-old son. I also had to take care of him. It was difficult to make breakfast for him and play with him in this period. This situation affected both me and my son negatively. People can think that if a woman has her first baby, she needs more help with baby care. However, it is not true. If a mother has the second baby, she needs most support for the care of her first child." (P3).

Another category of expected matter for support was time for themselves. Mothers want time especially for sleep, rest, and selfcare. According to most of the participants, one of the most difficult issues in this period was lack of sleep. They said that even if it is a few hours in the day, someone comes, takes care of the baby, and they can sleep. Moreover, some participants complained of not having time for themselves for self-care. Furthermore, because of the pain after the 
birth, they claimed they need more rest. Thus, time for rest was important for them to get over this period.

"It was enough for me that someone looked after the baby or was near the baby for just one hour. I need having a bath comfortably." (P5).

"I can overcome housework and babycare with the help of my partner. However, when he went to the job, I cannot rest. I had birth pain. Someone should have looked after my baby when my pain increased. I wished I can sleep and rest. It would help me a lot in this period." (P8).

The last category in the first theme was emotional support. Participants expected mostly emotional support besides support for housework.

"I did not need support for baby care or housework. I expected too much attention because I was too emotional in this period. I wanted to feel that people, especially my husband, were with me spiritually." (P14).

Second, the expectations from mothers and mothers-in-law theme were created with five categories. In this theme, which behaviors they expect or do not want from their mothers or mothers-in-law were tried to elaborate. Cooking and cleaning the house consisted of the first theme about their expectations from the mothers. As mentioned under the most expected matter for support, they expected support for housework from their mothers or mothers-in-law.

"My mother or mother-in-law did not come to my home to help me. I need them to help my housework or cook for us. I felt like an orphan.” (P3).

Another category was expecting support for baby-care but only when they wanted or asked for help. When their mothers helped baby-care when they wanted from them, they perceived this help as positive. However, they did not want their mothers and mothersin-law to involve too much in baby care. If mothers or mothers-in-law involved baby care too much as support, they did not perceive it as positive. Even the intention of the person who supported them was positive, when they perceived they were being mixed up in baby-care, this support did not make them feel better.

"Enough support for baby care was important. We can say whatever we need as support. Like my mother, if people ask what you need as help, this period was not difficult for us." (P7).

"The most important thing that made me worse in this period was that people especially mothers interfered with the care of my baby. They thought it was supporting, but it was not. They looked after my baby, put my baby to sleep, and changed the diaper. If they could, they would breastfeed my baby for me." (P9).

"Assistance with baby-care was good in this period, but just when we need. For instance, my mother-in-law should have looked after the baby, and thanks to it, we can go outside with my husband. However, when I was at home and did not want to sleep or have a rest, she should not have taken my baby from me." (P6).

In parallel to these, being understanding and not putting pressure on baby-care was another expectation from their mothers. Giving advice on baby care or commenting were perceived as pressure about baby care by new mothers. Also, they did not want their mothers' old customs about baby care.

"When my mother-in-law came to us, she wanted to help with babysitting. However, I did not want support for baby care because her old customs for babysitting did not make me feel better. She wanted to wash my baby with salt water, drink water and soup for my 20-day-old baby. It did not help me. It was a problem for me." (P2).

"I expected that people around me, especially mothers did not interfere with my baby-care. My mother-in-law always advised me like not to accustom the baby to lap. I read many books about baby care. I knew what was better for my baby. Also, we did not say these not to hurt them. They should understand us. We can decide everything about our baby." (P14). 
"People should not say us clothe the baby or give food to the baby. We know when our baby is hungry or cold." (P16, P8).

The other expectation was not being felt that they were inadequate or unskillful. Some behaviors of people give them these feelings. Also, some mothers-in-law said to new mothers that they were not enough for the baby or did not look after the baby well. It made them feel worse in this period. Also, according to them, hearing that your milk was not enough made them feel inadequate as a mother. Thus, mothers expected that people pay attention to their behavior and what they say in this period.

"You dressed the baby. My mother-in-law said the baby sweated, out of it. You dressed the baby thin. She said he's cold. She always said that you were inexperienced, and I knew better because I had raised many children. Having my mother-in-law with me in this period was not support, but rather it was stress for me." (P2).

"I did not live the feelings of the first motherhood freely. My mother-in-law and mother questioned whether the baby was sucking well or my milk was enough. I felt judged." (P8).

"My mother-in-law was anxious about her grandchild when she returned to her home. I thought that she did not trust me. However, in this period, one of the most important things was people should trust and encourage me. I was already anxious about whether I was enough for my baby. They made us feel worse in this period." (P13).

Financial support created the last category under the second theme. Some participants expected financial aid for their babies. This support helped them feel that they and their baby were valuable.

"My mother-in-law did not take any present to me or my baby. She did not even take any dress for my baby. We did not need it, but she should have offered it to me. She should give some money for example to take the baby's crib. It made me feel sad and invaluable in this period." (P5).
As the last theme, expectations from partners in the postpartum period theme was created. This theme consisted of five categories. The first one was assistance with the baby care. Participants expected support for baby care from their partners rather than their mothers or mothers-in-law. Taking care of the baby with their partners helped new mothers to cope with the postpartum period easily.

"I need the most support from my husband. It was the first time we had a baby. We did not know how we look after our baby. We would cope and learn together." (P4).

"We stayed with my husband and baby. It was a great experience for us. My mother came and cooked for us or cleaned the house. However, she did not interfere in baby care. Everyone would go home. We as a nuclear family remained together. Taking care of the baby together with my husband made us happier." (P7).

"Even if my partner took care of our baby and I could drink hot tea, it would be enough for me in this period." (P2).

Another category of the expectations from the partners was hearing that they were still loved and appreciated. They can have a sense of inadequacy because of the changes in their bodies and their roles at home. They can feel that they and their partners moved away from each other. Thus, feeling the love from their partners can be important in this period. Also, they can feel inadequate as a mother. Being made to feel that they were enough for the baby by their partners helped new mothers. Moreover, they wanted to feel that their partner was near them in this period. In short, they expected emotional support from their partners.

"My husband should understand and support me in terms of my anxiety about whether I am enough for my baby. Knowing he is with me and hearing "You are the best mother for us." would be the best thing I could easily overcome the difficulties in this period." (P8). 
"My husband did not help baby-care or housework. However, he supported me emotionally. He said that "You were a beautiful mother, and our baby was lucky to have you." This emotional support from my husband made me feel better. I can get through this period easily."'(P6).

"Support from my mother and mother-inlaw was not enough for me in this period. I did not feel better because I wanted to know that my partner was near with me." (P11).

Parallel to this category, another category was expecting attention and affection from the partners.

"The postpartum period is the period when women are most emotional. We expect attention. We need to be pampered by our partners." (P1).

Expecting more understanding consisted of another category. They wanted their partners to be more understanding in this period.

"At least my husband should be more understanding during this period. I cannot sleep at night. However, he expected me to make breakfast for him before he went to his job.” (P5).

The last category under the expectations from the partners was having time together with them. They feel suffocated at the home. According to the participants, they expected their partners to offer them to go outside to get some air.

"It's difficult to take care of the baby at home all day. I expected my partner to understand and ask me out for some air." (P17).

"It made me sad that my husband returned to work. I wanted to have time with him. Also, when he came home from his job, he was tired. He rested. However, I need him more." (P12).

With the answers from participants, it was aimed to examine new mothers' perceptions of social support in the postpartum period in this paper. Shortly, three main themes were constituted. For the first theme, the most expected matter for support according to new mothers occurred. Support for housework, the care of the older child if mothers have more than one child, having time for themselves, and emotional support were contained within the first theme. They answered the question of "In which matters do you receive the most support in this period and from whom?" as support for housework (cooking and cleaning). However, none of them answered support for baby-care to this question.

Expectations from mothers and mothersin-law were discussed as the second theme. They wanted their mothers and mothers-inlaw to cook meals for them and clean their house. Within this theme, it can be added that they wanted support for housework from their mothers and mothers-in-law. As another category, they expected assistance with baby care but only when they wanted it from their mothers or mothers-in-law. When they did not want assistance with baby care, helping baby care is seen as negative for them. They did not want them to be involved in baby care too much. They did not want them to hear advice or their old customs about their baby. Thus, they wanted to look after their baby alone or with their husbands. They expected their mothers to be near with them if they had any problem with the baby. Moreover, they can feel inadequate or unskillful because of behavior or statements of their mothers or mothers-in-law. Expecting to pay attention to it consisted as another subtheme for the expectations from mothers or mothers-in-law. Moreover, financial support was seen as another expectation under this theme.

The last theme in this paper was expectations from the partners in the postpartum period. They wanted their husbands to help with the baby care. They expected them to feel that they were still loved and appreciated by their husbands. They wanted to feel that their husbands were near. Thus, emotional support is an important topic for this theme. Also, expecting attention, affection, and more understanding from the husbands, and spending time with 
them consisted of other subthemes under expectations from the partners.

Based on these results, the content of the support can be seen as more important than the existence of social support for new mothers. Furthermore, according to the studies, although mothers have social support, they can experience psychological problems. ${ }^{22}$ These results also show that social support cannot be a protective factor for developing psychological problems in this period. The type of social support is more important instead of the existence of social support. It can contradict some research showing that social support is a protective factor in the postpartum period..$^{3,11}$ However, these findings are affected by culture, as mentioned before. The type of support and mothers' expectations are important to say whether social support is positive or not. For instance, as discussed, support for baby care can bother some mothers. They do not want any interference to baby-care, and they want to look after their babies alone. Also, because some mothers complained about traditional approaches for baby-care of their mothers or mothers-in-law, new mothers contradict them about babycare. Thus, new mothers do not expect support for baby care. In addition to the type of support, it can matter who gives the support. It can be seen that participants' mothers or mothers-in-law are more in the foreground in social support compared with their husbands. Studies show that new mothers expect support from their husbands rather than from their mothers or mothers-inlaw in the postpartum period. They want to determine baby-related decisions only with their partner. ${ }^{27}$ Besides the results of the study, participants mentioned that they wanted their husbands with them, and they need them most in this period. The result of the current study is in line with the studies in the literature.

\section{CONCLUSION AND RECOMMENDATIONS}

Social support can be important in the postpartum period. However, the results of the study showed that existence of the support in the postpartum period is not enough for mothers. The content of the support is more important than it. For example, support for baby care is not always seen as positive, while support for housework is one of the important types of expected support. Also, the people given the support are important for them. It can be summarized that they expect instrumental support, especially from their mothers or mothers-inlaw. Emotional support is the other type of support that they expected from their partners. Thus, type of the social support can be elaborated in studies on social support. It is well to increase qualitative studies on social support for the literature.

\section{REFERENCES}

1. Baser, M, Mucuk, S, Korkmaz, Z and Sevig, U. (2005). "The Determination of Mother and Father Newborn Care Needs in Postpartum Period". Journal of Health Sciences, 14, 54-58.

2. Robertson, E, Grace, S, Wallington, T. and Stewart, D.E (2004). "Antenatal Risk Factors for Postpartum Depression: A Synthesis of Recent Literature". General Hospital Psychiatry, 26 (4), 289-295.

3. Demir, S, Sentürk, M.B, Cakmak, Y. and Altay, M. (2016). "Postpartum Depression and Associated Factors in Patients Who Admitted to Our Clinic to Make Childbirth”. Haseki Tıp Bülteni, 54 (2), 83-89.

4. Stowe, Z.N. and Nemeroff, C.B. (1995). "Women at Risk for Postpartum-Onset Major Depression". American Journal of Obstetrics and Gynecology, 173 (2), 639-645.

5. Heron, J, O'Connor, T.G, Evans, J, Golding, J. and Glover, V. (2004). "The Course of Anxiety and Depression through Pregnancy and the Postpartum in a Community Sample". Journal of Affective Disorders, 80 (1), 65-73.
6. Gulnar, D, Sunay, D. and Caylan, A. (2010). "Risk Factors Related With Postpartum Depression". Journal of Clinical Obstetrics \& Gynecology, 20 (3), 141-148.

7. Robinson, G.E. and Stewart, D.E. (1986). "Postpartum Psychiatric Disorders". Canadian Medical Association Journal, 134 (1), 31-37.

8. Field, T, Sandberg, D, Garcia, R, Vega-Lahr, N, Goldstein, S. and Guy, L. (1985). "Pregnancy Problems, Postpartum Depression, and Early Mother Infant Interactions". Developmental Psychology, 21 (6), 1152 1156.

9. Lonstein, J.S. (2007). "Regulation of Anxiety during the Postpartum Period". Frontiers in Neuroendocrinology, 28 (2-3), 115-141.

10. Acele, E.O. and Karacam, Z. (2012). "Sexual Problems in Women during the First Postpartum Year and Related Conditions". Journal of Clinical Nursing, 21 (7-8), 929937. 
11. Xie, R.H, He, G, Koszycki, D, Walker, M. and Wen, S.W. (2009). "Prenatal Social Support, Postnatal Social Support, and Postpartum Depression". Annals of Epidemiology, 19 (9), 637-643.

12. Beck, C.T. (1995). "The Effects of Postpartum Depression on Maternal-Infant Interaction: A MetaAnalysis". Nursing Research, 44 (5), 298-304.

13. Doganer, G. and Bekar, M. (2006). "Vajinal Yolla Dogum Yapan Kadınların Erken Postpartum Donemde Kendisinin ve Yenidoganın Bakımına Yonelik Yasadıkları Sorunların Belirlenmesi”. Saglık ve Toplum, 16 (4), 60-70.

14. Beck, C.T. (2001). "Predictors of Postpartum Depression: An Update". Nursing Research, 50 (5), 275 285

15. Hung, C.H. and Chung, H.H. (2001). "The Effects of Postpartum Stress and Social Support on Postpartum Women's Health Status". Journal of Advanced Nursing, 36 (5), 676-684.

16. Herbert, P. (1994). "Support of First-Time Mothers in the Three Months after Birth". Nursing Times, 15 (24), 36-37.

17. Collins, N.L, Dunkel-Schetter, C, Lobel, M. and Scrimshaw, S.C. (1993). "Social Support in Pregnancy: Psychosocial Correlates of Birth Outcomes and Postpartum Depression". Journal of Personality and Social Psychology, 65 (6), 1243-1258.

18. Taylor, S.E, Welch, W.T, Kim, H.S. and Sherman, D.K (2007). "Cultural Differences in the Impact of Social Support on Psychological and Biological Stress Responses". Psychological Science, 18 (9), 831-837.

19. Cohen, S. and Wills, T.A. (1985). "Stress, Socia Support, and the Buffering Hypothesis". Psychological Bulletin, 98 (2), 310-357.

20. Marakoglu, K, Ozdemir, S. and Civi, S. (2009) "Postpartum Depresyon". Türkiye Klinikleri Journal of Medical Sciences, 29 (1), 206-214

21. Logsdon, M.C, McBride, A.B. and Birkimer, J.C. (1994) "Social Support and Postpartum Depression". Research in Nursing and Health, 17 (6), 449-457.

22. Bina, R. (2008). "The Impact of Cultural Factors upon Postpartum Depression: A Literature Review". Health Care for Women International, 29 (6), 568-592.

23. Stern, G. and Kruckman, L. (1983). "Multi-disciplinary Perspectives on Postpartum Depression: An Anthropological Critique". Social Science and Medicine, 17 (15), 1027-1041.

24. Morling, B, Kitayama, S. and Miyamoto, Y. (2003) "American and Japanese Women Use Different Coping Strategies during Normal Pregnancy". Personality and Social Psychology Bulletin, 29 (12), 1533-1546.

25. Stemler, S. (2000). "An Overview of Content Analysis". Practical Assessment, Research, and Evaluation, 7 (1), 17.

26. Baltaci, A. (2018). "Nitel Araştırmalarda Örnekleme Yöntemleri ve Örnek Hacmi Sorunsali Üzerine Kavramsal Bir İnceleme". Bitlis Eren Universitesi Sosyal Bilimler Dergisi, 7 (1), 231-274.

27. Hotun-Sahin, N, Dissiz, M, Dinc, H. and Soypak, F. (2014). "Erken Lohusalık Sürecinde Kadınların Algıladıkları Eş Destegi: Ölcek Geliștirme Çalışması". Anadolu Hemşirelik ve Sağlık Bilimleri Dergisi, 17 (2), 73-79. 